\title{
ANALYSIS OF COCOA PROCESSING AND MARKETING IN ABIA STATE,
} NIGERIA

\author{
Ejike, R.D.* and Chidiebere-Mark, N.M. \\ Department of Agricultural Economics, Extension and Rural Development, Imo State University, \\ Owerri \\ *ejikedabrechi@yahoo.com
}

\begin{abstract}
The study analysed Cocoa processing and marketing in Abia State, Nigeria. It specifically assessed the socio-economic characteristics of the cocoa processors, the structure and conduct of cocoa processors, cost and returns, marketing efficiency and constraints to cocoa processing and marketing in the study area. A total of 120 cocoa processors and marketers were randomly selected from the selected local governments purposively chosen using a multistage sampling procedure. Structured questionnaire was used to elicit information from cocoa processors who also engage in marketing of cocoa. Data were analysed using descriptive and inferential statistics. Results show that majority (56.7\%) of the processors and marketers were males, with a mean age of 51.35 years, literates (98.3\%), married (86.7\%), members of cooperative society (75\%,), had extension contact (60\%) and have a mean household size of 5 persons with 11.2 years processing and marketing experience. Cost and return analysis revealed that cocoa processing and marketing is a profitable venture and the marketers were efficient at their trade. Multiple Regression result revealed that Age, Educational level, household size, were significant variables that influence marketing efficiency of processors and marketers in the study area. Constraints identified include; transportation, spoilage, price fluctuation amongst others. The study recommends among others the provision of infrastructure like modern processing facilities and good road network by government to improve efficiency in processing and marketing of cocoa.
\end{abstract}

\section{Keywords: Cocoa processing, Cost-return, Efficiency, Marketing}

https://dx.doi.org/10.4314/jafs.v17i2.5

\section{INTRODUCTION}

Agriculture remains an important sector of the economy and accounted for $42.1 \%$ Gross Domestic Product (GDP) in Nigeria and employed about 79\% of the working population with about $80 \%$ of the country's poor working primarily in Agriculture (National Planning Commission, 2006). The need to diversify the productive base of the economy to reduce dependency on oil export and improve the agricultural sectors efficiency as well as intensify the growth potential of the private sector has placed cocoa enterprise as a topmost cash crop enterprise in Nigeria.

Journal of the Faculty of Agriculture and Veterinary Medicine, Imo State University Owerri website: www ajol.info 
Cocoa (Theobroma Cacao) is currently an important agricultural export crop in Nigeria with Nigeria producing about $5 \%$ of total world production (FAO, 2011). The contributions of cocoa to the nation's economic development are vast. In terms of foreign exchange earnings, no single agricultural export commodity has earned more than cocoa. A sizeable number of people are employed, both directly and indirectly in the cocoa sub-sector. In addition, it is an important source of raw materials, as well as a source of revenue to the economy. In terms of foreign exchange earnings, no single agricultural export commodity has earned more than cocoa (Nkang, 2009). Nigeria produces about 250,000 metric tonnes of cocoa (Adesina 2012). By these rating Nigeria competed favourable with other front liners in cocoa industry like Ivory Coast, Indonesia and Ghana. Prior to the oil boom of the mid 70's, Cocao (Theobroma Cocoa) was one of the highest foreign exchange earners in Nigeria and for a long time the crop has been generating substantial foreign earnings for the country (Onwumere and Alimba, 2010; Folayan et al, 2007). Cocoa is used for drinks, candies, cosmetics, soap and pharmaceuticals. It is grown in fourteen states of Nigeria, which includes Abia, Akwa Ibom, Cross River, Delta, Edo, Ekiti, Ogun, Ondo, Osun, Oyo, Kogi, Kwara, Adamawa and Taraba States.

Cocoa Processors Association of Nigeria (CPAN) has been clamoring for the ban on exportation of unprocessed cocoa bean to encourage processing locally. There was an attempt by the Nigeria government to ban export of cocoa beans in 1990 to promote local industrialization, increase foreign exchange earnings, and facilitate technology transfer. However, the ban was short-lived because of policy failure and pressure from stakeholders, especially Cocoa Association of Nigeria (CAN) which stressed that local industrial processing capacity was inadequate for handling the national cocoa beans output (Olomola et al, 2012).

In West Africa, the cocoa beans are marketed dry. Marketing is the critical link between farmer production sector on one hand and non-farm sector, industry and urban economy. The role of marketing in developing any economy including agriculture cannot be over emphasized. It involves all the legal, physical and economic services which are necessary in moving products from produce to consumers (Olukosi, Isitor and Ode, 2005). Cocoa marketing ensures the flow of product from processors to consumers in the form, time and place of need. Buyers are in need of the product while the sellers in turn need to improve their socio-economic status through higher profits and enhanced income.

Despite the fact that marketing provides the means of meeting these necessities (utilities) involved in the flow of goods and services; and therefore has an important multiplier effect in the development of any economy it is beset with a lot of problems which include unorganized and inefficient marketing system arising from seasonal variations, transportation, processing, storage, grading and communication (Anyaegbunam et al, 2011). The activities of middlemen hamper the effective distribution of cocoa which result in the high price of the produce. The dissolution of the Cocoa marketing board and the subsequent free marketing system introduced has allowed for a lot of illegalities in the marketing system as government has little or no influence in their activity. Also, Shortage of cocoa processing factories also adds to the problem of cocoa Journal of the Faculty of Agriculture and Veterinary Medicine, Imo State University Owerri website: www ajol.info 
production and marketing in Nigeria and this have resulted to the inefficiencies recorded in the cocoa industry.

These underlying problems have therefore necessitated the analysis of cocoa processing and marketing in Abia State, Nigeria with specific objectives to: identify the socio-economic characteristics of cocoa processors and marketers in the study area, ascertain the processing method of cocoa in the study area, ascertain marketing channel for cocoa, examine the market structure and conduct of cocoa processors and marketers, determine cost and returns of cocoa processing and marketing, determine marketing efficiency of cocoa marketers in the study area, estimate the effect of socioeconomic variable on marketing efficiency of processors and identify constraints to cocoa processing and marketing in the study area.

\section{MATERIALS AND METHOD}

The study was carried out in Abia State, Nigeria. The choice of Abia State for this study was termed to be appropriate given its antecedent in agriculture and food marketing particularly being an important cocoa growing state in Nigeria. Abia State occupies about 6,320 square kilometers and is bounded on the North and North East by the State of Anambra, Enugu and Ebonyi, to the West of Abia is Imo State, to the East and South East are Cross River and Akwa Ibom States and to the South is River State. It is one of the thirty-six states in Nigeria with seventeen local government areas and has a population of 2,845,380 (NPC, 2006). The farmers engage in Arable crop and livestock production such as cassava, yam, maize and sweet potatoes, poultry birds, goats and sheeps. Cocoa and oil palm are among the cash crops grown. The people also engage in processing, trading activities and civil service job.

Multistage sampling technique was used to select respondents for the study. Firstly, Ikwuano and Umuahia North were the two Local Governments purposively chosen because they are the major Cocoa producing areas in the State. Secondly, two communities from each of the selected Local Government Area (i.e Ibere, Oboro and Ibeku, Ohuhu respectively) were purposively selected due to high concentration of cocoa processing and marketing activities in the area. The third stage was the random selection of thirty processors who are also marketers from each of the communities, making it a total number of one hundred and twenty (120) Cocoa processors and this forms the sample size for the study. The sampling frame from which the Cocoa processors were selected was obtained from the Agricultural Development Program office in Abia State. Data were obtained with the use of structured questionnaire, administered through personal interview schedule. The questionnaire was designed to elicit information on processing and marketing activities, structure and conduct of Cocoa marketers, costs incurred in processing and marketing and constraints to Cocoa processing and marketing. Data were analyzed using descriptive statistics such as frequency distribution, percentages mean, and inferential statistics such as gross margin analysis, marketing efficiency as well as multiple regression technique.

The Gross Margin Analysis is given as;

$\mathrm{GM}=\mathrm{TR}-\mathrm{TVC}$

Journal of the Faculty of Agriculture and Veterinary Medicine, Imo State University Owerri website: www ajol.info 
Where;

$\mathrm{GM}=$ Gross Margin

$\mathrm{TR}=$ Total Revenue

$\mathrm{TVC}=$ Total Variable Cost

The net return represents the total profit and was determined using:

Net return $=\mathrm{TR}-\mathrm{TC}$ and $\mathrm{TC}=\mathrm{TFC}+\mathrm{TVC}$

Where;

$\mathrm{NR}=$ Net Return (profits)

$\mathrm{TR}=$ Total Revenue (price per bag $\mathrm{x}$ number of bags sold)

$\mathrm{TC}=$ Total Cost

TFC $=$ Total Fixed Cost

$\mathrm{TVC}=$ Total Variable Cost

The marketing efficiency (ME) of the Cocoa marketers was computed using the marketing efficiency index model as specified by Olukosi and Isitor, (1990) as:

$$
\mathrm{M} . \mathrm{E}=\frac{\text { Value added by marketing }}{\text { Total marketing cost }} 100
$$

The implicit form of the multiple regression model used is sated as follows;

$\mathrm{Y}=\mathrm{f}\left(\mathrm{X}_{1}+\mathrm{X}_{2}+\mathrm{X}_{3}+\mathrm{X}_{4}+\mathrm{X}_{5}+\mathrm{X}_{6}+\mathrm{X}_{7}+\mathrm{X}_{8}+\mathrm{X}_{9}+\mathrm{e}\right)$

Where;

$\mathrm{Y}=$ Marketing efficiency (percentage)

$\mathrm{X}_{1}=\operatorname{Sex}($ male $=1$, female $=0)$

$\mathrm{X}_{2}=$ Marital status (married $=1$, single $=0$ )

$\mathrm{X}_{3}=$ Age (years)

$\mathrm{X}_{4}=$ Household size (number of persons)

$\mathrm{X}_{5}=$ Level of Education (level of education attained)

$\mathrm{X}_{6}=$ Processing and marketing experience (years)

$\mathrm{X}_{7}=$ Corporative member $($ member $=1$, non-member $=0$ )

$\mathrm{X}_{8}=$ Access to credit

$\mathrm{X}_{9}=$ Extension contact

$\mathrm{e} \quad=\quad$ Stochastic error term

Journal of the Faculty of Agriculture and Veterinary Medicine, Imo State University Owerri website: www ajol.info 


\section{RESULTS AND DISCUSSION}

\section{Socio-Economic Characteristics of Cocoa Processors and Marketers}

Socio-economic characteristics of the respondents investigated in the study include sex, marital status, age, household size, level of education, years of experience, cooperative membership and extension contact. The results of the socioeconomic characteristics of the Cocoa processors are presented in Table 1. The result showed that $51.7 \%$ of the Cocoa processors and marketers were male while $48.3 \%$ were females. This implies that cocoa business in the study area was predominantly concentrated by male. Majority $(86.7 \%)$ of the respondents were married while $13.3 \%$ were single. This implies that married people were predominated in cocoa processing and marketing. Majority (33.33\%) of the processors were between the age brackets of 49-56years with an average age of 54.63 years. This is an indication that the respondents were in their economic active age. Majority (95\%) of the respondents has household size within $3-6$ with a mean household size of approximately 5 persons. This shows that the respondents had relatively large household size and this implies that they could draw family labour which would be cheaper than engaging hired labour in certain Cocoa processing and marketing activities. This in turn could enhance their marketing performance in Cocoa business.

Approximately, 83 percent of the respondents had formal education. This shows that the Cocoa processors in the study area are literate. This implies that processing and marketing efficiency could be enhanced through embracing innovative processing techniques and marketing strategies. Majority (31.67\%) of the respondents have between 10-13 years' experience in Cocoa processing and marketing with a mean experience of 11.2 years. Majority (75\%) of the processors belonged to a cooperative society. Membership of cooperative societies could improve their access to financial and technical support in the form of credit and training and other input resources as well as market information. It would also improve their market access with a relatively fair price deal for their product. All these could have a multiplier effect which is expected to boost their sales and increase their income. Majority (65\%) do not have access to credit as against $35 \%$ who have access to credit. Access to credit is an important factor needed to enhance processing and marketing efficiency of the respondent especially in the expansion of enterprise scale and acquisition of input resources. The result also revealed that $60 \%$ of the cocoa processors and marketers had extension contact. The implication is that extension contact can help improve their processing and marketing skills and to gain knowledge on best practices in the trade.

\section{Method of Processing Cocoa in the Study area}

The process of Fermentation was identified as the method used in cocoa processing in the study area. Fermentation of cocoa beans is one of the most important operations in the preparation of the beans for market. As a rule, maximum return is obtained only from properly fermented cocoa. After harvesting the cocoa pod, it is opened by knocking it against a blunt object. The beans are removed and placed in a basket covered with plantain leaves for $5-7$ days. This is Journal of the Faculty of Agriculture and Veterinary Medicine, Imo State University Owerri website: www ajol.info 
intended to reduce the water content in order to block enzymatic reactions. After the seven (7) days, the Cocoa beans are sun dried by spreading it on a level surface. The end product is then bagged and ready for market.

\section{Marketing Channel of Cocoa in Abia State}

The marketing channel for Cocoa in the study area is presented in Figure 1. The Figure shows the marketing channel for Cocoa in the study area. Various pathways were identified as the channels through which cocoa gets to the final consumer. The Cocoa producer supplies cocoa to the processor and the movement continues to the exporters who are merchants and down to the wholesaler, to the retailer and finally to the consumer. In this channel, there are four (4) middlemen involved; they are the processor, exporter, wholesaler and retailer. Other alternative routes can be from processor to retailer and to the consumer. The marketing agent acts between the processors and the exporters. They create the market link between merchants (exporters) and the processors and in some occasion help processors sell their produce.

\section{Market Structure and Conduct of Cocoa Processors}

\section{Market Structure}

Market structure is defined as the organizational and other characteristics of markets. It can also be defined as the characteristics of the markets either organizational or competitive that describe the nature of competition and the pricing policy followed in the market. In the study area, the processors buy Cocoa from the producers in their various farms and then process to cocoa beans. The processors who are also the marketers sell to buyers (exporters, wholesalers, retailers and the consumers) at $\$ 250$ per $\mathrm{Kg}$. There exist no entry barriers to either buyers or sellers. The product sold is homogenous. There is no individual marketer who has control over the market supply and price of cocoa. These characteristics liken the cocoa market in the study area to a perfect competition.

\section{Market Conduct}

Market conduct refers to the pricing and promotion strategies followed by the players in the market, in terms of their aims, objectives and decision making process. The market conduct is the pattern of commercial behaviour that firms follow in adjusting to the markets in which they sell or buy. These commercial behaviours arise from the existing market structure and include price determination behaviour, product behaviour, research and development, innovation, advertising, sales promotion policies, financial policy and collusion (https://www.oerafrica.org/FTPFolder/Agshare/Marketing\%20and\%20Price\%20Analysis/the_m arket_conduct.html, accessed 2/1/2020)

In the study area, the processors buy cocoa pods from producers and sell their processed cocoa as soon as they finish sun drying to various marketing agents (exporters, wholesalers, retailers and consumers). They sell at prices being reached by the seller/buyer bargain, no individual has the right to fix price or influence the quantity of cocoa supplied for sale. There is lack of Journal of the Faculty of Agriculture and Veterinary Medicine, Imo State University Owerri website: www ajol.info 
marketing information to enable processors and traders make meaningful market decision. Majority (90\%) of the cocoa processors and marketers belong to a cooperative society.

\section{Cost and Return of cocoa Processing and Marketing}

The result from Table 2 revealed the cost and return associated with cocoa processing and marketing in the study area. It showed that the average quantity of cocoa sold was $138 \mathrm{~kg} / \mathrm{month}$ and sold at $250 / \mathrm{kg} /$ month with a net profit of $\$ 13,141.9 / \mathrm{kg} /$ month. The total cost incurred was $\mathrm{N} 21,358.1 / \mathrm{kg} / \mathrm{month}$ with amount spent on purchasing unprocessed cocoa ( $\mathrm{N} 14,500 / \mathrm{kg} / \mathrm{month})$ and labour cost ( $1,500 / \mathrm{kg} /$ month) capturing major cost components incurred by processors in the study area. The marketing margin realized by processors/marketers was $60 \%$ indicating that for every naira invested in the trade, $\$ 60.00 \mathrm{kobo}$ is gained which suggest that cocoa processing and marketing is a profitable venture in the study area and this amount can be enhanced through expansion of processing scale and collective trading. The result is in agreement with the findings of Ahamefula et al., (2017).

\section{Marketing Efficiency of Cocoa Processing and Marketing}

Marketing Efficiency is the ratio of output of marketing system (value added) to input used in marketing system. The model is stated as follows;

M.E $=\underline{\text { Value added by marketing }} \times 100$

Total marketing cost

The Marketing efficiency was found to be $98.75 \%$ which denotes that Cocoa processing and marketing was economically efficient in the study area. This conforms to the findings of Folayan et al., (2007) who found that Cocoa marketers were economically efficient.

\section{Influence of Socio-economic Characteristics on the Marketing Efficiency of the Cocoa Processors}

The relationship between the socio-economic characteristics of the cocoa processors Marketing Efficiency is presented in Table 3. Four functional form were tried namely; Linear, Semi-log, Double-log and Exponential functions. The results show the multiple regression estimates of socio-economic characteristics of the Cocoa processors and marketers and their marketing efficiency. The model was tried in four functional forms, namely; linear, semi-log, double-log and exponential. Following statistical and econometric reasons, the linear form was chosen as the lead equation. This is because it provided the best fit. It has the highest value of coefficient of multiple determinations $\left(\mathrm{R}^{2}\right)$. From the Table, it revealed that at $1 \%$ significant level, the age of cocoa processors and marketers had a positive relationship with marketing efficiency of cocoa marketed in the study area, indicating that marketing efficiency increases with increase in the age of the marketers. This is contrary to the findings of Bassey et al., (2015) which opined that aged marketers are not innovative and lack the vigor to withstand the rigors in marketing. The explanatory variable, experience was significant at 5\% level and it had a positive relationship 
with marketing efficiency of cocoa processors and marketers in the study area, this implies that as the years of experience in processing and marketing increases, their efficiency in the business increases as the processors and marketers will have a good knowledge of the market information, forecast and predict what the future market holds and can apply strategies that can enhance their general performance in the trade. This result is in line with the findings of Obasi et al., (2012).

Sex, marital status, and extension contact of the processors and marketers were negatively signed and not significant indicating that they are not factors that determine efficiency in the business of cocoa processing and marketing in the study area. Marital status has an inverse relationship and significant at 5\% with marketing efficiency of processors and marketers indicating that marketing efficiency decreases with married processors and marketers than with unmarried processors and marketers. Level of education, household size, access to credit and cooperative membership coefficient were positively signed and significant at $1 \%, 5 \%, 1 \%$ and $5 \%$ respectively implying marketing efficiency increases with increase in each of these factors. Increase in them, increased cocoa sales among the respondents. Education brings to the processors and marketers a better understanding of what the market holds and how to maximize profit and minimize cost. The household size having a positive sign indicates that processors and marketers with large household size will be able to process and market more quantity because of the cheap labour provided by the household members and this can enhance income and also increase marketing outlet. Access to credit being positive implies that processors and marketers that have access to credit will have enough capital to purchase more cocoa and also help in buying some processing facilities. Cooperative membership being positive indicates that processors and marketers that belongs to a cooperative society have enough market information regarding price and have the opportunity to pool their resources together to enhance their processing and marketing activities, acquire cocoa supplies at subsidize rate and as well gain access to market in that way they can maximize efficiency in the trade.

The $\mathrm{R}^{2}$ value was 0.98 indicating that the variations in marketing efficiency were explained by the explanatory variables. The F-ratio $(301.920 * * *)$ was highly significant (1\% significance level) indicating the overall significance of the model hence the hypothesis that, there is no significant relationship between the socioeconomic characteristics of cocoa processors and marketing efficiency was rejected and the alternative was accepted that there is a significant relationship between both variables.

\section{Constraints of Cocoa Processing and Marketing}

Table 4 shows the constraints faced by processors in the processing and marketing of Cocoa in the study area. The results indicate that $68.83 \%, 85.83 \%, 76.67 \%, 45 \%, 56.67 \%, 50 \%$ and $40 \%$ of the respondents were faced with the problem of poor access road network, incessant price fluctuation, finance, spoilage, poor marketing information, poor processing and storage facilities and high transportation cost respectively. Problem of price fluctuation, finance and poor access

\section{Journal of the Faculty of Agriculture and Veterinary Medicine, Imo State University Owerri} website: www ajol.info 
road were ranked $1^{\text {st }}, 2^{\text {nd }}$ and 3 rd respectively as major constraints faced by processors and marketers.

\section{CONCLUSION AND RECOMMENDATION}

The study assessed cocoa processing and marketing in Abia State. It concludes that cocoa processing and marketing is a viable venture and the processors who were also marketers were efficient in cocoa trade. Market structure for cocoa was that of a perfect competition. The study recommends the provision of infrastructural facilities like well structured and functional market instituted to allow easy flow of market information, good processing and storage facilities to aid processing and marketing and reduce loss, good access roads to enable processors buy and convey their good to the market, processors and marketers should be encouraged to form agricultural cooperative societies to enhance collective trading, credit incentive price stabilization mechanism to enhance efficiency among processors and traders. 


\section{REFERENCES}

Abang, S. O. (1984). Stabilization Policy: An Economic Analysis and Evaluation of its Implication for Nigerian Cocoa Farmers. PhD Thesis, Oklahoma State University, Still Water p. 212.

Adesina, A. (2012). Nigeria to increase cocoa production. Special Address by Dr. Akinwumi A. Adesina Honourable Minister of Agriculture \& Rural Development Federal Republic of Nigeria to the World Cocoa Foundation Washington, D.C.

Ahamefule, B.A.; Igwe, C.O.K.; Offor, E.I.; Ekweanya, N.M. and Oyema, V.C. (2017). Profitability and operational efficiencies of Cocoa marketing in Abia State, Nigeria. Nigerian Agricultural Policy Research Journal , 3(1): 67-75.

Anyaegbunam, H. N.; Nwosu, A. C. and Mbasanor, J. A. (2011). Spatial Price Analysis of Sweet-potato Marketing in the South East Agric-ecological Zone of Nig. The Nigerian Agriculture Journal 42: 130 - 137.

Bassey, N.E., Uwemedimo, E.O., Uwem, U.I. and Edet, N.E. (2015) Analysis of the Determinants of fresh fish marketing and profitability among captured fish traders in South-South Nigeria: The case of Akwa Ibom State. British Journal of Economic, Management and Trade, 5(1): 35-45.

Food and Agricultural Organization (FAO) (2011). Helping to Build a World.

Folayan, J.A., Oguntade, A.E. and Ogundari, K. (2007). Analysis of Profitability and Operational Efficiencies of Cocoa Marketing: Empirical Evidence from Nigeria, Journal of Social Sciences, 15(2):197-199. doi: 10.1080/09718923.2007.11892582

National Planning Commission (NPC) (2006). Community-based Poverty Reduction Projects $(C P R P)$, Operational Manual, Abuja, Nigeria, Plc.

Nkang, N.M., Ajah, E.A., Abang, S.O. and Edet E.O. (2009). Investment in Cocoa Production in Nigeria: A Cost and Return Analysis of Three Cocoa Production Management Systems in the Cross River State Cocoa Belt. African Journal of Food, Agriculture, Nutrition and Development, 9(2): 713- 727.

Obasi I.O, Igwe K.C \& Nwaogu D.C. (2012) Determinants of profit of fish marketers in Umuahia and Ikwuano Local Government Area of Abia State, Nigeria. Proccedings of the 26th Annual Conference of Farm Management Association of Nigeria, October 15th19th, 2012.

Olomola, A.; Nwosu, A.C.; Oni, B.A.; Akande, S.O. and B. O. Akanji (2012). Prospects for Increased Value-added in Nigeria Cocoa Exports, NISER, Monograph Series No. 3.

Olukosi, J.O. and Isitor, S. V. (1990). Introduction to Agricultural Market and Price; Principles and Applications. Agitab Publishers. Zaria, pp34.

Journal of the Faculty of Agriculture and Veterinary Medicine, Imo State University Owerri website: www ajol.info 
Olukosi J. O., Isitor, S. U. and Ode, M. (2005). Introduction to Agricultural Marketing and Prices: Principles and Applications. Living Books Series G. U. Publications, Abuja FCT, pp. 115.

Onwumere, J. and Alimba C. S. (2010). Analysis of Socio-Economic Factors Affecting output of Farmers in three Management Systems of Cocoa production in Abia State, Nigeria. Global Approaches to Extension Practice Journal, 6 (2): 11 - 17.

www.oerafrica.org, accessed 2/1/2020) CAEE 5131 - Agricultural Marketing and Price Analysis. https://www.oerafrica.org/FTPFolder/Agshare/Marketing\%20and\%20Price\%20Analysis/ the_market_conduct.html 


\section{APPENDIXES}

Table 1: Socio-economic Characteristics of Cocoa Processors and Marketers

\begin{tabular}{|c|c|c|c|}
\hline Socioeconomic characteristics & Frequency & Percentage & Mean \\
\hline \multicolumn{4}{|l|}{ Sex } \\
\hline Male & 62 & 51.70 & \\
\hline Female & 58 & 48.30 & \\
\hline \multicolumn{4}{|l|}{ Marital status } \\
\hline Married & 104 & 86.70 & \\
\hline Single & 16 & 13.30 & \\
\hline \multicolumn{4}{|l|}{ Age (years) } \\
\hline $33-40$ & 12 & 10.00 & \\
\hline $41-48$ & 28 & 23.33 & \\
\hline $49-56$ & 40 & 33.33 & \\
\hline $57-64$ & 38 & 31.67 & \\
\hline $65-72$ & 2 & 1.67 & 51.35 \\
\hline
\end{tabular}

Educational level

No education

$2 \quad 1.70$

$\begin{array}{lll}\text { Informal education } & 12 & 10.00\end{array}$

$\begin{array}{lll}\text { Primary education } & 20 & 16.70\end{array}$

$\begin{array}{lll}\text { Secondary education } & 52 & 43.40\end{array}$

$\begin{array}{lll}\text { Tertiary education } & 34 & 28.30\end{array}$

Household size (no of persons)
$3-6$
$114 \quad 95.00$
$7-10$
$4 \quad 3.33$
$11-14$
$2 \quad 1.67$
4.88

Journal of the Faculty of Agriculture and Veterinary Medicine, Imo State University Owerri website: www ajol.info 
Journal of Agriculture and Food Sciences Volume 17 Number 2, October 2019 pp

Experience (years) $45-61$

$2-5$

$6-9$ 20

32

$10-13$

38

$14-17$

16

$18-21$

8

6

$22-25$

Co-operative membership

Non-member 30 25.00

Member

90

75.00

Extension contact

No contact

48

72

40.00

Contact with extension

Access to credit

No access

42

35.00

Access to credit

78

65.00

Total

120
16.67

26.67

31.67

13.33

Ejike, R.D. and Chidiebere-Mark, N.M.

6.66

5.00

11.20

Source: Field survey data, 2018

Journal of the Faculty of Agriculture and Veterinary Medicine, Imo State University Owerri website: www ajol.info 


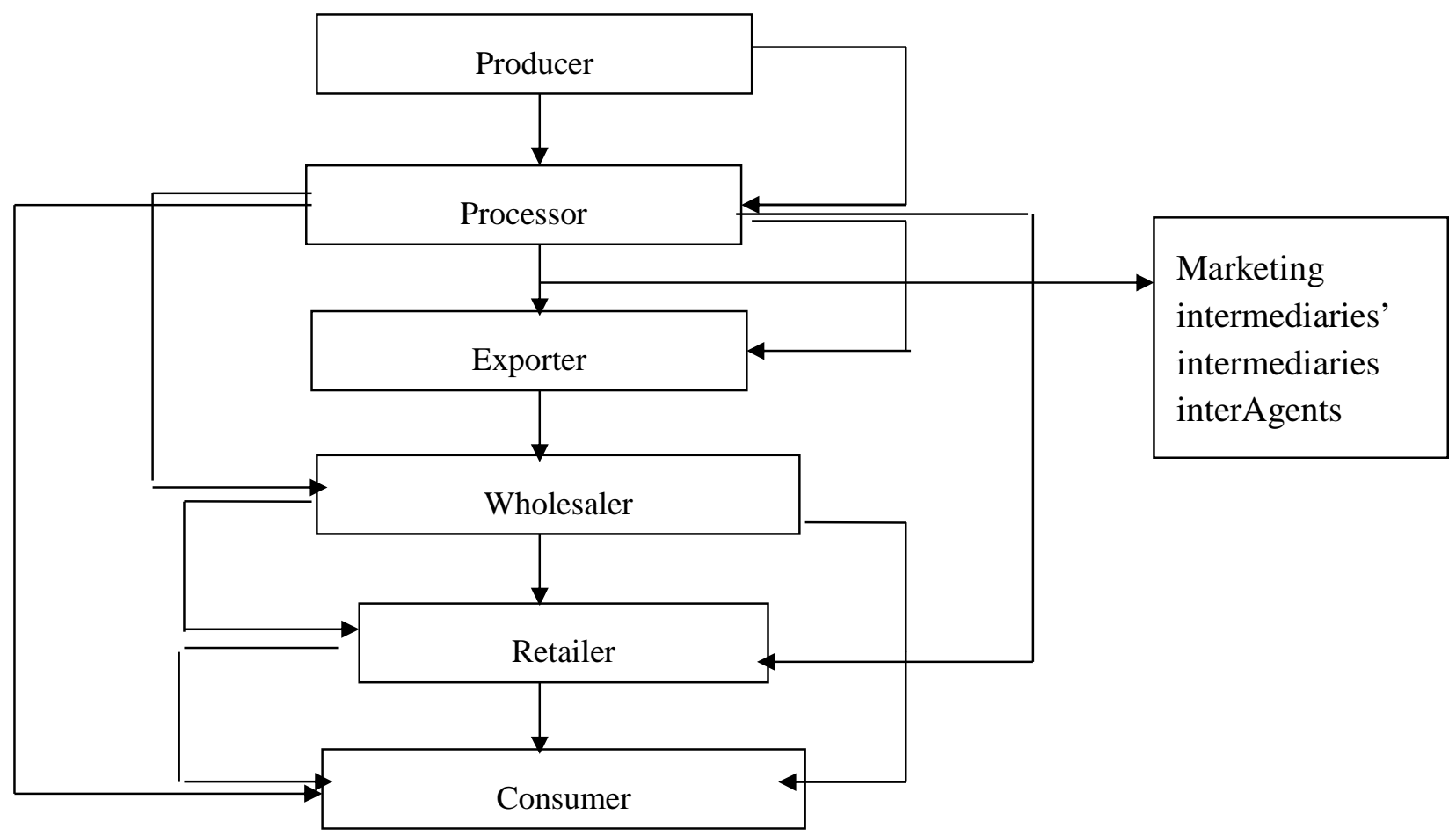

Fig. 1: Marketing channel for Cocoa in Abia State

Table 2: Cost-Return Analysis of Cocoa Processing and Marketing/Naira/KG/month

$\begin{array}{lllll}\text { Items } & \text { Unit } & \begin{array}{l}\text { Avg. Avg. Unit } \\ \text { Quantity }\end{array} & \begin{array}{l}\text { Total Value } \\ \text { Price (N) }\end{array} & \text { (N) }\end{array}$

\section{A. Revenue}

Sales from processed Cocoa

$(\# / k g) \quad 138$

250

B. Variable Cost

$(\#)$

Purchase price of unprocessed $(\mathbb{\$} / \mathrm{kg})$

cocoa

Market charges

$(\#)$

100

100

Transportation

(き)

200

200

Journal of the Faculty of Agriculture and Veterinary Medicine, Imo State University Owerri website: www ajol.info 


\begin{tabular}{|c|c|c|c|c|}
\hline Loading \& offloading & (\#) & & 600 & 600 \\
\hline Agent fees & (\#) & 1 & 500 & 500 \\
\hline Labour & $(\mathrm{N})$ & 2 & 750 & 1500 \\
\hline Total variable cost & $(\#)$ & & & 17,400 \\
\hline C. Fixed Cost & (\#) & & & \\
\hline Rent & $(\AA)$ & & & 3,500 \\
\hline \multicolumn{5}{|l|}{ Depreciation on equipment: } \\
\hline Basin & Number & 2 & 58.3 & 116.6 \\
\hline Drying mat & Number & 2 & 33.3 & 66.6 \\
\hline Knife & Number & 2 & 12.5 & 25.0 \\
\hline Jute bag & Number & 3 & 16.7 & 33.4 \\
\hline Scale & Number & 1 & 83.3 & 83.3 \\
\hline Sickle & Number & 2 & 12.5 & 25.0 \\
\hline Basket & Number & 2 & 20.8 & 41.6 \\
\hline Tray & Number & 2 & 33.3 & 66.6 \\
\hline Total fixed cost & $(\AA)$ & 16 & 270.7 & $3,958.1$ \\
\hline Total cost $(B+C)$ & & & & 21358.1 \\
\hline Gross profit (TR - TVC) & & & & 17,100 \\
\hline NET Profit (GP - TFC) & & & & $13,141.9$ \\
\hline Marketing margin & & & & $60 \%$ \\
\hline Marketing efficiency & & & & $61.53 \%$ \\
\hline
\end{tabular}

Source: Field Survey Data, 2018. 
Table 3: Influence of Socio-economic Characteristics on the Marketing Efficiency of the Cocoa Processors

\begin{tabular}{|c|c|c|c|c|}
\hline Variables & Linear & Semi-log & Double-log & Exponential \\
\hline \multirow[t]{2}{*}{ Constant } & 9.170 & 141.113 & 4.498 & 4.763 \\
\hline & $(0.914)$ & (1.317) & $(11.480)^{* * *}$ & $(122.881)^{* * *}$ \\
\hline \multirow[t]{2}{*}{ Sex } & -0.071 & -0.025 & 0.000 & 0.000 \\
\hline & $(-0.515)$ & $(-0.183)$ & $(-0.474)$ & $(-0.737)$ \\
\hline \multirow[t]{2}{*}{ Age } & 0.094 & 29.956 & 0.031 & 0.000 \\
\hline & $(3.992) * * *$ & $(3.342)^{* * *}$ & (1.019) & $(1.211)$ \\
\hline \multirow[t]{2}{*}{ Educational Level } & 0.056 & 61.114 & 0.124 & 0.000 \\
\hline & $(3.839)^{* * *}$ & $(3.217)^{* * *}$ & $(1.782)^{*}$ & $(2.099)^{* *}$ \\
\hline \multirow[t]{2}{*}{ Household size } & 2.090 & 8.238 & 0.024 & 0.006 \\
\hline & $(2.434) * *$ & $(1.985)^{* *}$ & (1.615) & $(1.710)^{*}$ \\
\hline \multirow[t]{2}{*}{ Marital status } & -31.482 & -32.407 & -0.079 & -0.072 \\
\hline & $(-2.435)^{* *}$ & $(-2.229)^{* *}$ & $(-1.485)$ & $(-1.449)$ \\
\hline \multirow[t]{2}{*}{ Experience } & 0.176 & 74.009 & 0.234 & 0.000 \\
\hline & $(2.369)^{* *}$ & $(2.537)^{* *}$ & $(2.194)^{* *}$ & $(1.710)^{*}$ \\
\hline \multirow{2}{*}{$\begin{array}{l}\text { Cooperative } \\
\text { membership }\end{array}$} & 30.024 & 30.717 & 0.080 & 0.075 \\
\hline & $(2.291)^{* *}$ & $(2.109)^{* *}$ & (1.507) & (1.488) \\
\hline \multirow[t]{2}{*}{ Access to credit } & 1.028 & 1.001 & 0.003 & 0.003 \\
\hline & $(17.088)^{* * *}$ & $(16.235)^{* * *}$ & $(12.286)^{* * *}$ & $(12.660)^{* * *}$ \\
\hline \multirow[t]{2}{*}{ Extension contact } & -1.457 & -1.394 & -0.005 & -0.005 \\
\hline & $(-0.453)$ & $(-0.410)$ & $(-0.437)$ & $(-0.369)$ \\
\hline F-ratio & $301.920 * * *$ & $270.986 * * *$ & $184.883 * * *$ & $183.998 * * *$ \\
\hline $\mathrm{R}^{2}$ & 0.982 & 0.980 & 0.971 & 0.971 \\
\hline
\end{tabular}

Source: Field survey data, 2018.

$* * *=1 \%$ significance level, $* *=5 \%$ significance level and $*=10 \%$ significant level

Figures in parenthesis are the t-values

Journal of the Faculty of Agriculture and Veterinary Medicine, Imo State University Owerri website: www ajol.info 
Table 4: Distribution of the respondents by constraints encountered in Cocoa processing and marketing

\begin{tabular}{|c|c|c|c|}
\hline Problems & Frequency* & $\begin{array}{l}\text { Percentage } \\
(\%)\end{array}$ & Rank \\
\hline Poor access road networks & 79 & 68.83 & $3^{\text {rd }}$ \\
\hline Incessant Price fluctuation & 103 & 85.83 & $1^{\text {st }}$ \\
\hline Finance & 92 & 76.67 & $2^{\text {th }}$ \\
\hline Spoilage & 54 & 45.0 & $6^{\text {th }}$ \\
\hline Poor market information & 68 & 56.67 & $4^{\text {th }}$ \\
\hline $\begin{array}{l}\text { Poor processing and storage } \\
\text { facilities }\end{array}$ & 60 & 50.0 & $5^{\text {th }}$ \\
\hline High transportation cost & 48 & 40.0 & $7^{\text {th }}$ \\
\hline
\end{tabular}

Source: Field Survey Data, 2018.

Multiple Responses recorded* 